Volume 12 Number 4, October-December 2018: pp. 284-297. Copyright (c) 2019 FIAT JUSTISIA. Faculty of Law, Lampung University, Bandarlampung, Lampung, Indonesia. ISSN: 1978-5186 | e-ISSN: 2477-6238.

Fiat Justisia is licensed under a Creative Commons Attribution 4.0 International License, which permits unrestricted use, distribution, and reproduction in any medium, provided the original work is properly cited.

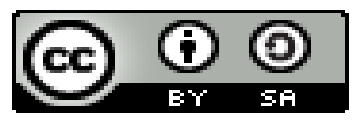

\title{
The Realization of Social Justice for the Poor Citizens According to Legal Philosophy
}

\author{
Naomi Jesica \\ University of Tarumanagara, Indonesia \\ naomihartanto@yahoo.com \\ Meta Nadia \\ University of Tarumanagara, Indonesia \\ metanadiaw@gmail.com \\ Lusi Septiyati \\ University of Tarumanagara, Indonesia \\ lusiseptiyati@gmail.com
}

\begin{abstract}
Pancasila is an ideology of Indonesia. One of the precepts of Pancasila is the principle of Social Justice for All Indonesians implies that all Indonesian people have the same position before the law. But nowadays, there have been many cases of injustice against the poor citizens. Therefore this research journal is about the realization of social justice for the underprivileged people in the philosophy of law, especially based on the theory named Critical Legal Studies.

Keywords: Critical Legal Studies, Injustice, and Poor Citizens

How to Cite: Naomi Jesica, Meta Nadia, and Lusi Septiyati, "The Realization of Social Justice for the Poor Citizens According to Legal Philosophy", Fiat Justisia, 13 (1), (2019).

DOI: https://doi.org/10.25041/fiatjustisia.v12no4.1383
\end{abstract}




\section{A. Introduction}

In each country, it has a different purposes. In Indonesia the purpose of the country is in the Preamble of the 1945 Constitution paragraph 4 which reads "Kemudian daripada itu untuk membentuk suatu Pemerintah Negara Indonesia yang melindungi segenap bangsa Indonesia dan seluruh tumpah darah Indonesia dan untuk memajukan kesejahteraan umum, mencerdaskan kehidupan bangsa, dan ikut melaksanakan ketertiban dunia yang berdasarkan kemerdekaan, perdamaian abadi dan keadilan sosial, maka disusunlah Kemerdekaan Kebangsaan Indonesia itu dalam suatu Undang Undang Dasar Negara Indonesia, yang terbentuk dalam suatu susunan Negara Republik Indonesia yang berkedaulatan rakyat dengan berdasarkan kepada Ketuhanan Yang Maha Esa, Kemanusiaan yang adil dan beradab, Persatuan Indonesia dan Kerakyatan yang dipimpin oleh hikmat kebijaksanaan dalam Permusyawatan/Perwakilan, serta dengan mewujudkan suatu Keadilan Sosial bagi seluruh rakyat Indonesia".

It can be concluded that in the opening of the fourth paragraph of the 1945 Constitution the objective of the State of Indonesia is to provide protection to its citizens, improve people's welfare, provide education for the nation's children as a successor to the nation and state play an active role in maintaining world order based on independence, peace eternal and social justice. The main thing is to provide protection to its citizens and improve people's welfare. The protection of citizens and improving the welfare of society is also manifested in the values contained in Pancasila, especially the fifth principle of the Pancasila.

Pancasila consists of five precepts, which is a philosophical system in essence of an organic entity. This reality is called objective reality, namely that reality exists in the Pancasila itself apart from something else or apart from people's knowledge. So that the philosophical system is distinctive and different from other philosophies. Philosophically the Pancasila includes the ontological basis, epistemological basis, and axiological basis.

Pancasila is the basis of state ideology. Pancasila contains the views of life, soul, personality and life goals of the Indonesian people. Pancasila as the basis of state ideology that cannot be changed into any form. Pancasila is essentially a unifying value system of the state, especially for the diversity in Indonesian nation.

Pancasila is the basis of a state philosophy. Pancasila is a guideline for the state and law of the Republic of Indonesia in its concretes and not just in its abstract. ${ }^{1}$ Pancasila has a basic vision that is based on human nature. It is this basic vision that gives the vision and direction for all Indonesian society and state life.

\footnotetext{
${ }^{1}$ Notonagoro, Pancasila Secara Ilmiah Populer, Jakarta: Pantjuran Tujuh, (1980), p. 174.
} 
Every principle in Pancasila contains different values. Especially in the fifth principle of Pancasila which reads "Social justice for all Indonesian people". The principle of social justice for all Indonesians shows that Indonesian people realize that they have the same rights and obligations. Justice itself contains the meaning of virtues related to human relations. ${ }^{2}$ The consequences of social justice must be realized, such as elements of equality, equality and freedom. That for all Indonesian people, equality and equality must be realized before the law.

This day, talking about justice there is a lot of cases of injustice in law, especially for poor citizens. Poor citizens who are to be identical with the poor. In Article 34 of the Constitution which contains that the poor and neglected children are cared for by the state, the state develops a social security system for all people and empowers people who are weak and unable to comply with human dignity, the state is responsible for providing health care facilities and decent public service facilities. According to Law Number 13 of 2011 concerning Poor Management, Article 1 Number 1, the poor are people who have absolutely no source of search and / or have a source of livelihood but do not have the ability to fulfill basic needs that are appropriate for their lives and / or his family. The low standard of living causes the inability of individuals to fulfill both material and non-material needs.

Many poor citizens experience discrimination before the law. One of the cases that occurred was the case of 55-year-old Minah from Banyumas, only because she stole 3 cocoa fruits which cost no more than Rp. 10,000 sentenced to 1.5 years in 2009. In fact, for transportation costs to court, she had to borrow Rp. 30,000 because the distance from her house was quite far from the court. In addition to the case examples above there are still many other case examples that will be described in different chapters. This case example is certainly not in accordance with the implementation in Article 34 of the Basic Law which states that the poor are cared for by the state. Though the state should be responsible for this, especially in terms of law enforcement.

Such cases should be concerned because this means that the values that contained in Pancasila regarding social justice for all Indonesian people are not realized in reaching all social layers. For the elaboration outlined, the author think that this problem really needs to be discussed so that people are increasingly aware of these events or something similar happens to the general public. Based on the title "The Realization of Social Justice for the Poor Citizens According to Philosophy of Law" the problem that the author wants to discuss is how is the realization of social justice for poor citizens according to Critical Legal Studies?

\footnotetext{
${ }^{2}$ Muhamad Erwin, Filsafat Hukum Refleksi Kritis Terhadap Hukum, Jakarta: Raja Grafindo Persada, (2011), p.223.
} 


\section{B. Method}

The method used by the author is in the form of writing normative law. Normative legal writing is a process to find a rule of law, legal principles and legal doctrines to answer the legal issues of the rule of law of legal principles, as well as legal doctrines.

\section{Analysis and Discussion}

\section{Justice}

The original words for justice comes from the word "fair" from the Arabic al-adl, which means straight in the soul not being defeated by Eve talking lust, not as evil, balanced, equal and so on. In the United Kingdom, the term language of Justice, mentioned by various terms, such as: justice (translated: fairness, propriety, correctness and the judiciary), fairness (translated with honesty), equaty (translated: righteousness, According to fairness and reasonableness) and impartiality (translated with justice, impartial, honest attitude, the attitude of fairness, honesty and a neutral attitude). ${ }^{3}$ In Kamus Besar Bahasa Indonesia (KBBI), justice is an adjective describing the noun or pronouns which has three meanings. Pertama, sama berat; tidak berat sebelah; tidak memihak. Kedua, berpihak kepada yang benar. Ketiga, sepatutnya, tidak sewenang-wenang. ${ }^{4}$

The oldest meaning of justice formulated by law experts at the time of the Romans in Latin "Justitia est constans et perpetua voluntas jus suum cuique tribuendi", translation in English is "Justice is the constant and perpetual will to render to each man what is his due". ${ }^{5}$ The meaning of Justice from the Roman times is still influential in the Western in giving the understanding of Justice. According to A.I. Goodhart, it is generally accepted that the essence of the idea of Justice is "to render to each man what is his due". ${ }^{6}$ I.P. Plamenatz expressed his opinion that the meaning of justice is "giving every man his due, and the setting, either by compensating the victim of wrong or by punishing the doer of it "(give everyone what must be, and correcting either by providing

\footnotetext{
${ }^{3}$ Purwanto, "Perwujudan Keadilan dan Keadilan Sosial Dalam Negara Hukum Indonesia: Perjuangan yang Tidak Mudah Dioperasionalkan", Jurnal Hukum Media Bhakti, 1(1), (2018). p. 3.

${ }^{4}$ Ahmad Fadlil Sumadi, "Hukum dan Keadilan Sosial dalam Perspektif Hukum Ketatanegaraan Law and Social Justice in Constitutional Law Perspective", Jurnal Konstitusi, 12 (4), (2016), p.857.

${ }^{5}$ Pramono, Nindyo dan Sularto, Hukum Kepailitan dan Keadilan Pancasila, Yogyakarta: Andi, (2017), p.2.

${ }^{6}$ Ibid.
} 
compensation to the victims or to punish the perpetrators of that mistake). ${ }^{7}$ In The Encyclopedia Americana (1973) give some definition of Justice that one of them is "the constant and perpetual disposition to render every man his due" or a fixed and eternal tendency to give each person what is necessarily. ${ }^{8}$

On the basis of such understanding, then the main meaning of Justice is giving to each person what is appropriate. Next that needs to be explained further what is meant by "give what should be". According to Mortimer Adler, the concept of the giving to each person what is proper, contains two important prespectives that is different and each one cannot be derived from or returned at the other. The meaning of "what should be" for everyone can be determined with (1) the size of the rights of the person, rather it is a natural right or rights originating in the applicable law, and (2) a comparison of the capabilities or services from one person to someone else. Based on the two aspects of the right and the comparison, the sense of "what should be" for everyone have two forms, namely:

a. Guarantee of the rights in order to be free from violations

b. The treatment it deserves, i.e. treating the same things in the same way and things that are not the same in not equally balanced way with the inequality of that.

\section{The Meaning of Poor Citizens}

According to Kamus Besar Bahasa Indonesia (KBBI), masyarakat kurang mampu atau masyarakat miskin adalah masyarakat dalam keadaan dimana terjadi ketidakmampuan untuk memenuhi kebutuhan dasar seperti makanan, pakaian, tempat berlindung, pendidikan, dan kesehatan. Kemiskinan dapat disebabkan oleh kelangkaan alat pemenuhan kebutuhan dasar, ataupun sulitnya akses terhadap pendidikan dan pekerjaan. ${ }^{9}$

About the benchmark of poverty, according to Sayogo is the amount of calories that are eaten per capita. Poverty is determined at the limit of 1700 calories a day per capita. This limit already is under the normal needs of the people of Indonesia who need more than 2000 calories per day. ${ }^{10}$ According to the conclusions of the Research Centre for the study of Bandung Institute of technology in 1992, although Indonesia has abundant wealth, but in reality that as much as $61.6 \%$ of households classified as poor farmers in Indonesia with the criteria income of IDR 50,000.-(now estimated at Rp 500,000,-) or

\footnotetext{
${ }^{7}$ Ibid.

${ }^{8}$ Ibid., p.3.

${ }^{9}$ Hakki Fajriando, "Masalah Hukum Implementasi Pemenuhan Hak Atas Layanan Bantuan Hukum Bagi Masyarakat Miskin”, Jurnal Ham, 7(2), (2016), p.132.

${ }^{10}$ Soemitro dan Ronny H, Perspektif Sosial Dalam Pemahaman Masalah-Masalah Hukum, Semarang: Agung Press, (1989), p.63.
} 
less per month per family. ${ }^{11}$ Meanwhile, according to Alex Emyll, MSP (1992), the criteria for borderline poverty is a revenue of Rp. 20.000- or less per months per individuals.

According to BPS (2007), families that do not have the capacity to fulfill basic needs or people who have a source of livelihood but cannot fulfill their family needs that are appropriate for humanity with the following characteristics or criteria: ${ }^{12}$ (i) Low expenditure or below the poverty line, which is less than Rp.175,324 for urban communities, and Rp.131,256 for rural communities per person per month outside of non-food needs; (ii) Education levels are generally low and have no skills; (iii) Not having a habitable residence, including not having a MCK; (iv) Ownership of assets is very limited in number or value; (v) Social relations are limited, not have been involved in many community activities; and (vi) Limited access to information (newspapers, radio, television and internet).

\section{Justice Theory}

Aristotles issued a theory of justice. In his theory, Aristotles put forward five types of actions which can be classified as fair. The five types of justice proposed by Aristotle are as follows: ${ }^{13}$

a. Commutative Justice

Commutative justice is the treatment of someone by not seeing the services that have been given. Example: A person who has made a mistake/violation, regardless of his position, he is still punished according to the mistake/violation he made.

b. Distributive Justice

Distributive justice is the treatment of someone according to the services they have given. Example: Some employees of a company earn different salaries, based on their tenure, class of rank, level of education, or the level of difficulty of their work.

c. Nature's Natural Justice

Nature's natural justice is giving something according to what is given by others to us. Example: A person who answers the greeting spoken by another person is said to be fair because he has received greetings from that person.

d. Conventional Justice

11 Suteki, "Implikasi Kebijakan Formulasi Penggunaan Alokasi Dana Bagi Hasil Cukai Tembakau Terhadap Program Pembinaan Lingkungan Sosial”, Law Reform, 13(2), (2017). p. 267.

${ }^{12}$ Ibid.

${ }^{13}$ Aim Abdulkarim, Pendidikan Kewarganegaraan untuk Kelas XI, Jakarta: Grafindo Media Pratama, (2006), p.57. 
Conventional justice is only if a citizen has obeyed all laws and regulations that have been issued.

e. Justice Improvement

Fair actions according to justice improvement are if someone has tried to restore the good name of others who have been polluted.

\section{The Value of Justice in the Fifth Precept of Pancasila}

The value of justice is found in the fifth principle of the Pancasila, namely the principle of social justice for all the people of Indonesia. According to Notohamidjojo, social justice demands that humans live properly in society. Each must be given a chance. Development and implementation of development do not only need to rely on and realize justice, but also propriety. The term human propriety can also be called fair or proportional propriety. ${ }^{14}$

In the Precept of Social Justice for all Indonesian people contained the value of social justice, including: ${ }^{15}$

1. Fair treatment in all aspects of life, especially in the fields of politics, economics and socio-culture.

2. The realization of social justice for all the people of Indonesia

3. Balance between rights and obligations

4. Respect other people's rights

5. The ideals of a prosperous society that are materially and spiritually equitable for all the people of Indonesia

6. Love of progress and development.

The fifth precept in Pancasila implies that every Indonesian society is aware of the same rights and obligations to create social justice in the lives of Indonesian people. For this reason, behavior was developed which reflected the attitude and atmosphere of family and mutual cooperation and needed a fair attitude towards others, maintaining continuity between rights and obligations and respecting the rights of others.

The principle of social justice for all Indonesian people contains values that every legal regulation, both law and court decision reflects the spirit of justice. Justice is one of the law purposes. Law must carry the value of justice. The purpose of law is to achieve a sense of justice in society. ${ }^{16}$ The value of Justice must be applicable in people's lives, especially in the aspect of law enforcement. In the judicial process, the judge in deciding each case must

\footnotetext{
14 Darmodiharjo, Darji dan Shidarta, Pokok-Pokok Filsafat Hukum, Apa dan Bagaimana Filsafat Hukum Indonesia, Jakarta: Gramedia Pustaka Utama, (2008), pp. 156-157.

${ }^{15}$ Prasetyo, Teguh dan Abdul Halim Barkatullah, Filsafat, Teori, \& Ilmu Hukum Pemikiran Menuju Masyarakat yang Berkeadilan dan Bermartabat, Jakarta: RajaGrafindo Persada, (2012), p. 375.

${ }^{16}$ Santoso, H.M.Agus, Hukum, Moral, \& Keadilan, Jakarta: Prenada Media Group, (2014), p. 91.
} 
prioritize the value of Justice regardless of legal facts. Justice seeks to prevent the abuse of power by the stronger party against weaker parties.

Law is a tool to uphold justice and create social welfare. Essential justice is justice that is found in society. ${ }^{17}$ Without justice as its goal, the law will fall into a means of justifying the arbitrariness of the majority or the authorities against minorities or those who are controlled.

The value of justice contained in the fifth Pancasila precept if it is associated with the theory of justice according to Aristotles, then the justice that is referred in this case is commutative justice someone must be treated the same way by not seeing the services that has been provided then in this case the judge must enforce the law. A case with no regard for its position but purely because of a mistake that has been made. The judge must decide according to the mistakes and violations made by the perpetrator. But in practice, this is not implemented in accordance with the expectations and conditions of the Indonesian people because there are still many cases of injustice against underprivileged citizens in terms of law enforcement by judges.

\section{Critical Legal Studies}

Critical Legal Studies is a movement that emerged in the 70s in the United States. ${ }^{18}$ For the critical legal stream the law that used by modern law as a form of democracy and the market is a lie and never existed. The law for modern law has been built in with das sollen democracy same as responsive law, but das sein in the basis of the formation of formal law is the political arena through the procedure of attraction of the interests of those who are incorporated in that authority.

The critical legal studies tries to answer by basing their thoughts on several general characteristics as follows: ${ }^{19}$

a. The critical legal studies criticizes law that is full and dominant with certain ideologies.

b. This critical stream of legal studies criticizes the applicable law which in fact siding with politics and law as such it is not neutral at all.

c. The critical legal studies has a great commitment to individual freedom with certain limitations. Because of this, this philosophy has a lot to do with human emancipation.

\footnotetext{
${ }^{17}$ Salim, H. dan Erlies Septiana Nurbani, Penerapan Teori Hukum pada Penelitian Disertasi dan Tesis, Jakarta: RajaGrafindo Persada, (2014). p. 27.

${ }^{18}$ Nasution, Muhammad Syukri Albani, Hukum Dalam Pendekatan Filsafat, Jakarta: Kencana, (2016), p.186.

${ }^{19}$ Lili Rasjidi, Dasar-dasar Filsafat Hukum. Bandung: Citra Aditya Bakti, (1996), pp. 132-133.
} 
d. The critical legal studies lacks of trust in abstract forms of truth and truly objective knowledge. Because of this the critical legal studies strongly rejects teaching in the legal positivism flow.

e. The critical legal studies rejects the act between theory and practice also rejects the difference between fact and value, which is a characteristic of liberalism.

Critical legal studies reject the notion of traditional law experts, namely: the law is objective, meaning that reality is a legal foothold, the law is certain, meaning that the law provides a definite and understandable answer, the law is neutral, meaning that it does not favor certain parties, and the law is autonomous, meaning that it is not influenced by politics or other sciences. Furthermore, critical legal flow tells some basic concepts as follows: ${ }^{20}$

a. Critical legal studies rejects liberalism.

b. Critical legal studies presents the contradictions between individuals and other individuals as well as with the community.

c. Critical legal studies of do a legitimation in the community so far, reinforced by the principles of hegemony and reification, actually strengthens the oppression of the strong / powerful against the weak.

d. Critical legal studies rejects the life model of liberal society which is actually more of an engineering or falsehood that is strengthened by the legal sector. This principal is trying to overhaul the legal reasoning system that is full of falsehood.

e. Critical legal opinion argues that legal doctrine is something that is uncertain and full of contradictions, so it can be interpreted arbitrarily by the interpreter.

f. Because of the uncertain nature of legal doctrine, this school uses a more historical, socio-economic, and psychological model of legal analysis and interpretation.

g. Critical legal thinking holds that juridical analysis obscures the real reality, which gives birth to a ruling as if it is just and legitimate.

$h$. There is no neutral interpretation of a legal doctrine, but the interpretation is always subjective and political.

The flow of critical legal studies holds that the law is certain. Therefore, the law is contradictory internally and the same provisions can always be interpreted or applied differently and even contradict each other.

\section{The Realization of Social Justice for the Poor Citizens in Legal Philosophy}

${ }^{20}$ Fx. Adji Samekto, Studi Hukum Kritis: Kritik Terhadap Hukum Modern. Bandung: Citra Aditya Bakti, (2005), p. 69. 
The principle of social justice for all Indonesian people contains values that every legal regulation, both law and court decision reflects the spirit of justice. Social justice in this 5 th principle implies that all people have equality before the law. Rich or poor people have the same rights and obligations, and also have the same position in court. This justice must be felt by most Indonesian people, not by a handful of certain groups.

But in reality the realization of social justice for all Indonesian people is still being done. The realization of social justice, especially for the poor, is still very minimal. Many cases of injustice have happened to them. The following are examples of cases:

a. The case of theft of flip-flops by AAL, Brigadier Rusdi Harahap as law enforcement officers who directly accused AAL and carried out vigilante acts and treated AAL arbitrarily. AAL and his friends were beaten, kicked, punched and even held captive by Brigadier Rusdi Harahap. AAL was decided by the Palu Court, Central Sulawesi that he was formally found guilty even though the sandals that were being used as evidence were not "eiger" brand sandals alleged by Brigadier Rusdi Harahap. The sandals stolen by AAL are "Ando" not "Eiger" which is meant by Brigadier Rusdi Harahap. So that the sandals taken by AAL are menless sandals. When taking sandals that were not manned it was like taking a fish in the sea. AAL should not be found guilty. ${ }^{21}$

b. The case of Asyani (63), she was charged with stealing seven stems of teak trees claimed by Perhutani in her home in the village of Jatibanteng Situbondo, East Java. In the trial at the Situbondo District Court, Asyani was charged with Article 12 letters c and d jo article 83 paragraph (1) letter a of Law No. 18 of 2003 concerning Prevention and Eradication of Forest Destruction $(\mathrm{P} 3 \mathrm{H})$, with the threat of at least 1 year and a maximum of 5 years in jail. Asyani felt that she did not steal Perhutani's wood, the wood she cut was her wood which had been around her house for decades. ${ }^{22}$

c. Cases of poor people in Bojonegoro, Supriyono and Sulastri. They are husband and wife. They were tried in court without having a strong legal basis and were threatened with a sentence of seven (7) years imprisonment. Supriyono and Sulastri are in custody accused of stealing a bunch of bananas, worth Rp. 15,000.00. Both reported by Maskun as the owner of the banana, and Bambang and Muis to the police. As a result of the report, both were processed legally through the court. Although there

\footnotetext{
${ }^{21}$ Ashinta Sekar Bidari, (2014). "Ketidakadilan Hukum Bagi Kaum Sandal Jepit”, Ratu Adil Jurnal Hukum dan Kebijakan Sosial, 3(2), (2014), p. 5.

${ }^{22}$ Umar Sholahudin, "Hukum dan Keadilan Masyarakat (Analisis Sosiologi Hukum terhadap Kasus Hukum Masyarakat Miskin "Asyani” di Kabupaten Situbondo", Dimensi Journal of Sociology, 9(1), (2016), p. 32.
} 
was no evidence Supriyono-Sulastri had stolen a bunch of bananas, the police and prosecutors continued to process the case. This case has also been reconciled at the level of the Neighborhood Unit (RT) and village witnessed by the police. However, the husband and wife remain on the table. ${ }^{23}$

d. Minah, who is working in the field, picking three cacao fruits belonging to PT Rumpun. The cocoa tree is about 165 centimeters tall. Minah, which is 160 centimeters tall, slightly tiptoe when picking it. After picking three cacao fruits with her bare hands, Minah put them under the tree. While looking, one by one the cocoa fruit was skinned. That's when Sutarno, the plantation foreman, arrived. Sutarno interrogates Minah. According to Sutarno, Minah claimed to take the cocoa. Minah apologizes to Sutarno while crying. But Sutarno still reported Minah's actions to PT Rumpun. PT Rumpun's manager then reported Minah's actions to the Ajibarang Sector Police. After that, Minah was summoned by the police, prosecutors and the court, three times each. Until the 1-month and 15-day sentence of imprisonment was dropped: Minah was proven to steal three cacao fruits, which cost only around Rp. 2,100. ${ }^{24}$

However, if these cases are compared to corruption cases, for example the case regarding the corruption case of the Chairman of the Bengkalis DPRD, Heru Wahyudi. The Panel of Judges of the Pekanbaru District Court, Riau, handed down a mild verdict against the Chairman of the Bengkalis DPRD, Heru Wahyudi. Even though he was found guilty of corruption in social assistance funds, he was only sentenced to 18 months in prison. This verdict is very contrary to the demands of the prosecutor. The prosecutor sued Heru with a sentence of eight years and six months in prison and a fine of Rp. 500 million, 6 months in prison. ${ }^{25}$

If it is seen from the results of the decision, according to the author, this is very unfair for the poor. Viewed through the philosophy of law, especially the Critical Legal Studies. In this principle, critical legal studies reject the notion of traditional lawyers, namely: law is objective, meaning that reality is a legal ground, that law is certain, meaning that the law provides definite and understandable answers, the law is neutral, meaning that it is impartial to certain parties. and the law is autonomous, meaning that it is not influenced by politics or other sciences. The critical legal studies holds that the law is certain. Therefore, the law is contradictory internally and the same provisions

\footnotetext{
${ }^{23}$ Ibid.

${ }^{24}$ Umar Sholahudin, "Membangun Keadilan Restoratif Bagi Si Miskin”, Sejarah dan Budaya, 7(1), (2013), p. 36.

${ }^{25}$ M Syukur, Kasus Korupsi Rp 31 M, Ketua DPRD Bengkalis Divonis 1,5 Tahun Bui, https://www.liputan6.com/regional/read/2974957/kasus-korupsi-rp-31-m-ketua-dprdbengkalis-divonis-15-tahun-bui, 29 Agustus 2018.
} 
can always be interpreted or applied differently and even contradict each other.

This Critical Legal Studies is very appropriate according to the author with what is happening in law in reality these days. That the law is no longer neutral, but the law is certain because the applicable law which in fact takes sides with politics and law as such is not neutral at all. It can be seen through the results of the judge's decision that decided on cases of corruption and theft committed by the poor people. Judges' decisions are not commensurate with the differences in deeds they have committed. Corruption is an act that is quite detrimental to the community and the state and corruption cases should not be sentenced with a light sentence while the punishment for poor people whose actions are only small violation is being punished by a strict punishment.

So according to the author the realization of social justice for the poor citizens seen from the philosophy of law specifically seen from the Critical Legal Studies. That the author feels it is very true that the law is no longer neutral so that the legal objectives regarding justice are not realized, especially justice for the poor.

\section{Conclusion}

The values of Pancasila contains justice where everyone should be treated equally regardless of their position in particular especially in enforcement of law by the judge in court. When judges made their decision, they should not see the defendant based on their position. However, this is principal not implemented in accordance with expectations and conditions of Indonesia society because, in many cases there are injustice happening in Indonesia especially against the poor citizens, many of them are terminated with severe penalty as compared with the corruptor that had caused many disadvantage to the people of Indonesia.

So according to the Author law is not neutral anymore. The law in fact disinterested and not purely about the law. This is apparent from the verdict against the corruptor and theft by poor citizens. The Government should be more aware of what really happened in the court especially judges when they made their decision they should not see the defendant based on the position and be fair. They should reflects justice as in the theory of Justice it's called commutative justice, where judges abstain in matters, they decide based on their mistakes.

Based on what has been described in this journal, then the goal is about the realization of social justice for poor citizens in the philosophy of law. Additionally the author expects that social justice can be done indiscriminately before the law. Thus, the authors suggest to readers especially citizens of Indonesia and Government especially law enforcement officers, to be more assertive and fair in applying social justice, in terms of handling as well as the 
overthrow of punishment that should be as fair as possible may be applied according to the causes that the defendant has done. With appropriate penalties obtained according the results of the existing losses. Recommendation for law enforcers are not lame in seeing legal issues that occur and they supposed to know the issues that very harmful for our country, so that later on in the overthrow of punishment justice can be done with impartial to the rich people only. So that social justice not only mere wishful thinking

\section{A. Book}

\section{Bibliography}

Abdulkarim, Aim. (2006). Pendidikan Kewarganegaraan untuk Kelas XI. Jakarta: Grafindo Media Pratama.

Darmodiharjo, Darji dan Shidarta. (2008). Pokok-Pokok Filsafat Hukum, Apa dan Bagaimana Filsafat Hukum Indonesia. Jakarta: Gramedia Pustaka Utama.

Erwin, Muhamad. (2011). Filsafat Hukum Refleksi Kritis Terhadap Hukum. Jakarta: Raja Grafindo Persada.'

H, Ronny dan Soemitro. (1989). Perspektif Sosial Dalam Pemahaman Masalah-Masalah Hukum, Semarang: Agung Press.

Nasution. Muhammad Syukri Albani. (2016). Hukum Dalam Pendekatan Filsafat, Jakarta: Kencana.

Notonagoro. (1980). Pancasila Secara Ilmiah Populer, Jakarta: Pantjuran Tujuh.

Pramono, Nindyo dan Sularto. (2017). Hukum Kepailitan dan Keadilan Pancasila. Yogyakarta: Andi.

Prasetyo, Teguh dan Abdul Halim Barkatullah. (2012). Filsafat, Teori, \& Ilmu Hukum Pemikiran Menuju Masyarakat yang Berkeadilan dan Bermartabat. Jakarta: RajaGrafindo Persada.

Rasjidi, Lili. (1996). Dasar-dasar Filsafat Hukum. Bandung: Citra Aditya Bakti.

Salim, H. dan Erlies Septiana Nurbani. (2014). Penerapan Teori Hukum pada Penelitian Disertasi dan Tesis. Jakarta: RajaGrafindo Persada.

Samekto. Fx. Adji. (2005). Studi Hukum Kritis: Kritik Terhadap Hukum Modern. Bandung: Citra Aditya Bakti.

Santoso, H.M.Agus. (2014). Hukum, Moral,\& Keadilan, Cetakan ke-2. Jakarta: Prenada Media Group.

\section{B. Journal and Article}

Ahmad Fadlil Sumadi, "Hukum dan Keadilan Sosial dalam Perspektif Hukum Ketatanegaraan Law and Social Justice in Constitutional Law Perspective", Jurnal Konstitusi, $12 \quad$ (4), (2016). https://doi.org/10.31078/jk1249 
Ashinta Sekar Bidari, (2014). "Ketidakadilan Hukum Bagi Kaum Sandal Jepit”, Ratu Adil Jurnal Hukum dan Kebijakan Sosial, 3(2), (2014)

Hakki Fajriando, "Masalah Hukum Implementasi Pemenuhan Hak Atas Layanan Bantuan Hukum Bagi Masyarakat Miskin", Jurnal Ham, 7(2), (2016), https://doi.org/10.30641/ham.2016.7.172

Purwanto, "Perwujudan Keadilan dan Keadilan Sosial Dalam Negara Hukum Indonesia: Perjuangan yang Tidak Mudah Dioperasionalkan", Jurnal Hukum Media Bhakti, 1(1), (2018). https://doi.org/10.32501/jhmb.v1i1.2

Suteki, "Implikasi Kebijakan Formulasi Penggunaan Alokasi Dana Bagi Hasil Cukai Tembakau Terhadap Program Pembinaan Lingkungan Sosial", Law Reform, 13(2), (2017). https://doi.org/10.14710/lr.v13i2.16160

Umar Sholahudin, "Hukum dan Keadilan Masyarakat (Analisis Sosiologi Hukum terhadap Kasus Hukum Masyarakat Miskin "Asyani” di Kabupaten Situbondo", Dimensi Journal of Sociology, 9(1), (2016).

Umar Sholahudin, "Membangun Keadilan Restoratif Bagi Si Miskin", Sejarah dan Budaya, 7(1), (2013).

\section{World Wide Web}

Syukur, M. Kasus Korupsi Rp 31 M, Ketua DPRD Bengkalis Divonis 1,5 Tahun Bui. https://www.liputan6.com/regional/read/2974957/kasuskorupsi-rp-31-m-ketua-dprd-bengkalis-divonis-15-tahun-bui, Agustus 2018. 